\title{
EFFECT OF BURNT BRICK DUST ON ENGINEERING PROPERTIES ON EXPANSIVE SOIL
}

\author{
Sachin N. Bhavsar ${ }^{1}$, Hiral B. Joshi ${ }^{2}$, Priyanka k. Shrof ${ }^{3}$, Ankit J. Patel ${ }^{4}$ \\ ${ }^{1}$ B.E. final year, Civil Department, SVBIT, Gujarat, India \\ ${ }^{2}$ B.E. final year, Civil Department, SVBIT, Gujarat, India \\ ${ }^{3}$ B.E. final year, Civil Department, SVBIT, Gujarat, India \\ ${ }^{4}$ M.Tech (Structural Design), Assistant Professor, SVBIT, Gujarat, India
}

\begin{abstract}
The black cotton soil is known as expansive type of soil which expands suddenly and start swelling when it comes in contact with moisture. Due to this property of soil the strength and other properties of soil are very poor. To improve its properties it is necessary to stabilize he soil by different stabilizers. Expansive type of soil shows unpredictable behavior with different kind of stabilizers. Soil stabilization is a process to treat a soil to maintain, alter or improve the performance of soil. In this study, the potential of burnt brick dust as stabilizing additive to expansive soil is evaluated for the improving engineering properties of expansive soil. The evaluation involves the determination of the swelling potential, linear shrinkage, atterberg's limits, \& compaction test of expansive soil in its natural state as well as when mixed with varying proportion of burnt brick dust (from 30 to 50\%). The practices have been performed on three proportions 30\%, 40\%, and 50\% with expansive soil. The research result shows considerable reduction in swelling of expansive soil .With increasing amount of stabilizer swelling decreases. Maximum decrement in swelling has been noted in 50\% of replacement of soil by brick dust. Also by increasing stabilizing content linear shrinkage reduces. Maximum decrement in shrinkage has been noted in 50\% replacement of soil by stabilizer. Maximum dry density of soil is improving and optimum moisture content is decreasing with increasing stabilizing content. For increasing content of stabilizing agent brick dust atterberg's limit values are also decreasing.
\end{abstract}

Keywords: expansive soil, stabilization, burnt brick dust, engineering properties

\section{INTRODUCTION}

"Expansive soil is commonly known as black cotton soil because of their colour and their suitability for growing cotton." It starts swell or shrink excessively due to change in moisture content. When an engineering structure is associated with black cotton soil, it experiences either settlement or heave depending on the stress level and the soil swelling pressure. Design and construction of civil engineering structures on and with expansive soils is a challenging task for geotechnical engineers. The solution of this soil is stabilization with appropriate stabilizing agent. The black cotton soil contains high percentage of montomonillonite which renders high degree of expansiveness. These property results cracks in soil without any warning. The behaviour of black cotton soil is uncertain when subjected to moisture content. The strength properties of these soils change according to the amount of water contained in the voids of the soils. The engineering behaviour of fine-grained soils depends on their water content. Liquid limit and plastic limit are important water contents as well as two important parameters of plasticity index, which is the main index parameter of the classification of fine-grained soils. Plasticity index has also been used in correlation with many other engineering properties like internal friction angle, undrained shear strength, lateral earth pressure over consolidation ratio etc. Shrinkage limit is also an important parameter in which soils tend to shrink when they lose moisture. [1]

One of the challenges faced by civil engineers is the design of foundation for sites having expansive Soils. Most economical and effective method for stabilizing expansive soils is using admixtures that present change in volume. Many problems arise from the industrial development. One of them is the proper and effective disposal of its waste. Generally, industrial waste causes many serious environment problems. So utilization of industrial waste in construction industry is the best way to dispose it. Using industrial waste in construction industry is beneficial in many ways such as disposal of waste, saving biodiversities, increasing soil properties like strength, reduce permeability, etc., preserve the natural soil and making economical structures. Expansive soils contain the clay mineral montinorillonite with claystones, shales, sedimentary and residual soils. Clay exists in the moisture deficient, unsaturated conditions. [2] 


\section{DAMAGE ANALYSIS \& PROBLEM DEFINED FOR EXPANSIVE TYPE OF SOIL [1]}

Black cotton soil is one of the major regional soil deposits in India, covering an area of about 3.0 lacks sq.km. Expansive soils are problematic soils because of their inherent potential to undergo volume changes corresponding to changes in the moisture regime. When they imbibe water during monsoon, they expand and on evaporation thereof in summer, they shrink. Because of this alternate swelling and shrinkage, structures founded on them are severally damaged. The annual cost of damage to the civil engineering structures is estimated at $£ 150$ million in the UK, $\$ 1000$ million in the USA and many billions of pounds worldwide.

Infrastructural developments in areas where problem soils are identified have been a major concern to the engineer. As such, infrastructure like roads, buildings, bridges to mention but a few within such areas normally undergo foundation problems, that lead to a reduction in the life span of such facilities. Since there is an increasing shortage of good construction materials within localities where problem soils are encountered in addition to the high cost of haulage, what readily comes to mind is making the unsuitable materials fit for use by modification. It is important either to remove the existing soil and replace it with a non-expansive soil or to improve the engineering properties of the existing soil by stabilization. Replacing the existing soil might not be a feasible option; therefore, the best available approach is to stabilize the soil with suitable stabilizers.

Various types of soil stabilizers (i.e. fly ash, cement kiln dust, lime) and locally available materials (i.e., slate dust, rice husk ash) are being used for stabilization of soil. However, the selection of a particular type of stabilizer depends upon the type of sub grade soil and availability of stabilizers. Several researchers have reported the benefits of stabilizers for modifying the engineering properties of soil.

\section{STABILIZATION [3]}

"Soil stabilization is a technique aimed at increasing or maintaining the stability of soil mass and chemical alteration of soil to enhance their engineering properties."

Stabilization allows for the establishment of design criteria as well as the determination of the proper chemical additive and admixture rate to be used in order to achieve the desired engineering properties. Benefits of the stabilization process can include higher resistance values, reduction in plasticity, lower permeability, reduction of pavement thickness, elimination of excavation material hauling or handling. Stabilization of expansive soils with admixtures controls the potential of soils for a change in volume, and improves the strength of soils.
Soil stabilization is done by various methods by adding fly ash, rise husk ash, chemicals, fibers, adding lime, by different geo materials like geo synthetic, geo grid and geo form. Soil stabilization allows engineers to distribute a larger load with less material over a longer life cycle.

\subsection{ADVANTAGES OF SOIL STABILIZATION}

1) Stabilized soil functions as a working platform for the project

2) Stabilization waterproofs the soil

3) Stabilization improves soil strength

4) Stabilization helps reduce soil volume change due to temperature or moisture

5) Stabilization improves soil workability

6) Stabilization reduces dust in work environment

7) Stabilization upgrades marginal materials

8) Stabilization improves durability

9) Stabilization dries wet soils

10) Stabilization conserves aggregate materials

11) Stabilization reduces cost

\section{REVIEW}

\subsection{Mine Tailing Mixtures on Lime Treated Soil [4]}

H.N.Ramesh, A.J.Krishnaiah and S.Shilpa shet from Department of Civil Engineering, UVCE, Bangalore University, Bangalore-56, India in april-2013 conducted tests on lime treated black cotton soil by adding mine tailing mixtures as a stabilizing agent.

Liquid limit, plastic limit and shrinkage limit of Black cotton soil and mine tailings (MT) mixtures treated with lime are investigated and are presented in this paper. In the present investigation an attempt has been made to utilize the mine tailings in geotechnical applications and to evaluate the index properties of black cotton soil and mine tailings mixture treated with lime. The test results indicate that the progressive decrease in liquid limit, decrease in plastic limit and increase in shrinkage limit with curing time. Liquid limit is used for the estimation of compression index which is useful for the settlement analysis of soils.

\subsection{Sisal Fibres [5]}

Santhi Krishna k. And sayida M.K from department of civil engineering, collage of engineering Trivandrum, kerala analysed the behaviour of black cotton soil by reinforcing it from sisal fibres.

A large part of Central India and a portion of South India are covered with black cotton soils. These soils have high swelling and shrinkage characteristics and extremely low CBR value and shear strength. Hence, there is need for improvement of these properties. The present study is aimed at determining the behavior of black cotton soil reinforced with 
sisal fibre in a random manner. The soil used is a type of black cotton soil collected from Chittur in Palaghat District. The fibres are cut to different lengths $(1.5 \mathrm{~cm}, 2.0 \mathrm{~cm}, 2.5 \mathrm{~cm}$ and $3.0 \mathrm{~cm})$ and mixed randomly with soil in varying percentages $(0.25 \%, 0.50 \%, 0.75 \%$ and $1.00 \%)$ by dry weight of soil and compacted to maximum dry density at optimum moisture content. The test results indicate a reduction in the maximum dry density and the optimum moisture content of soil due to the addition of sisal fibre.

\subsection{Fly-ash Stabilization [6]}

Erdal Cokca (2001):- Effect of Fly ash on expansive soil was studied by Erdal Cokca, There are two major classes of fly ash, class C \& F. He carried out investigations using Soma Fly-ash and Tuncbilek fly-ash and added it to expansive soil at $0-25 \%$. Specimens with fly-ash were cured for $7 \& 28$ days after which they were subjected to oedometer free swell tests. And his experimental findings confirmed that the plasticity index, activity and swelling potential of the samples decreased with increasing percent stabilizer and curing time and the optimum content of fly ash in decreasing the swell potential was found to be $20 \%$. The changes in the physical properties and swelling potential are a result of additional silt size particles to some extent. He concluded that both high calcium and low calcium class $\mathrm{C}$ fly ashes can be recommended as effective stabilizing agents for improvement of expansive soils.

\subsection{Rice Husk Ash, Lime, Gypsum [7]}

Koteswara Rao .D and Anusha .M from department of civil engineering of University College of Engineering JNTUK KAKINADA, A.P. has conducted an experimental study on stabilization of black cotton soil with rice husk ash, lime and gypsum. This study, resulted in considerable improvement in the strength characteristics of the expansive soil. Liquid limit of the soil has been decreased by $22 \%$ for $20 \%$ RHA $+5 \%$ Lime. Free Swell Index has been reduced by $88 \%$ for $20 \%$ RHA $+5 \%$ Lime. UCS of the expansive soil has been increased by $548 \%$ for $20 \%$ RHA $+5 \%$ lime $+3 \%$ Gypsum after 28 days curing. CBR value was increased by $1350 \%$ for $20 \%$ $\mathrm{RHA}+5 \%$ lime $+3 \%$ Gypsum after 14 days curing. There is remarkable influence on strength and CBR values for $20 \%$ RHA $+5 \%$ Lime $+3 \%$ Gypsum which is an optimum percentage.

\section{PROPERTIES OF BLACK COTTON SOIL}

The expansive type of soil is in black color and also it has ability to grow cotton it is known as black cotton soil. This type of soil expand suddenly when came in contact of moisture and start swell and shrink when the moisture is removed so due to its swell- shrink behavior it is a very problematic soil for consideration of its use as a construction material.
Table 1: properties of soil

\begin{tabular}{|l|l|}
\hline Coarse sand (\%) & $0.3 \%$ \\
\hline Medium sand (\%) & $3.02 \%$ \\
\hline Fine sand (\%) & $24.34 \%$ \\
\hline Silt \& clay (\%) & $72.34 \%$ \\
\hline Liquid limit & $43 \%$ \\
\hline Plastic limit & $16.897 \%$ \\
\hline Plasticity index & $26.1 \%$ \\
\hline Maximum dry density & $1.71 \mathrm{~g} / \mathrm{cc}$ \\
\hline Optimum moisture content & $18.08 \%$ \\
\hline Linear shrinkage & $0.23 \%$ \\
\hline Free swell index & $50.5 \%$ \\
\hline
\end{tabular}

\section{EXPERIMENTAL SETUP}

In this present paper we are performing atterberg's limits test, linear shrinkage test, free swell index, and modified proctor test for determination of dry density and moisture content on black cotton soil and the mix proportions of black cotton soil and marble powder with $30 \%, 40 \%, \& 50 \%$ replacement of soil by its dry weight.

Table 2: Tests and IS code determination

\begin{tabular}{|l|l|}
\hline Grain Size Analysis & IS 2720 (part IV) 1985 \\
\hline Atterberg's Limits & IS 2720 (Part V) 1985 \\
\hline Modified Proctor Test & IS: 2720 (Part VIII) 1983 \\
\hline Linear Shrinkage & IS 2720 (Part 20)-1992 \\
\hline Free Swell & IS 2720 (Part 40)-1977 \\
\hline
\end{tabular}

\subsection{Grain Size Analysis IS 2720 (part IV) 1985}

Analysis by Wet Sieving - The portion of the soil passing 4.75-mm IS Sieve obtained as given in 3.2 shall be oven-dried at 105 to $110^{\circ} \mathrm{C}$. The oven-dried material shall then be riffled so that a fraction of convenient mass is obtained. This shall be about $200 \mathrm{~g}$ if a substantial proportion of the material only, just passes the $4.75-\mathrm{mm}$ IS Sieve or less if the largest size is smaller. The fraction shall be weighed to 0.1 percent of its total mass and the mass recorded. The riffled and weighed fraction shall be spread out in the large tray or bucket and covered with water.

Two grams of sodium hexametaphosphate or one gram of sodium hydroxide and one gram of sodium carbonate per litre of water used should then be added to the soil. The mix should be thoroughly stirred and left for soaking. The soil soaked specimen should be washed thoroughly over the nest of sieves specified in nested in order of their fineness with the finest sieve (75-micron IS Sieve) at the bottom. Washing shall be continued until the water passing each sieve is substantially clean. Care shall be taken to see that the sieves are not 
overloaded in the process. The fraction retained on each sieve should be emptied carefully without any loss of material in separate trays. Oven dried at 105 to $110^{\circ} \mathrm{C}$ and each fraction weighed separately and the masses recorded.

Alternatively, the soaked soil specimen may be washed on the 75-micron IS Sieve until the water passing the sieve is substantially clean. The fraction retained on the sieve should be tipped without loss of material in a try, dried in the oven and sieved through the nest of sieves, either by hand or by using mechanical sieve shaker. The fraction retained on each sieve should be weighed separately and the masses recorded.

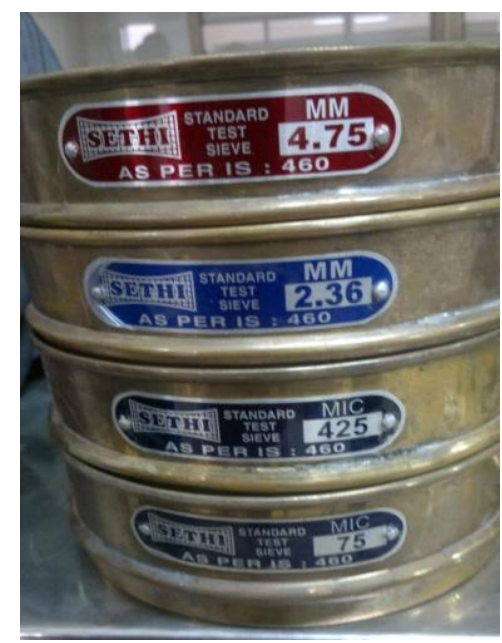

Fig 1: Arrangement of sieves

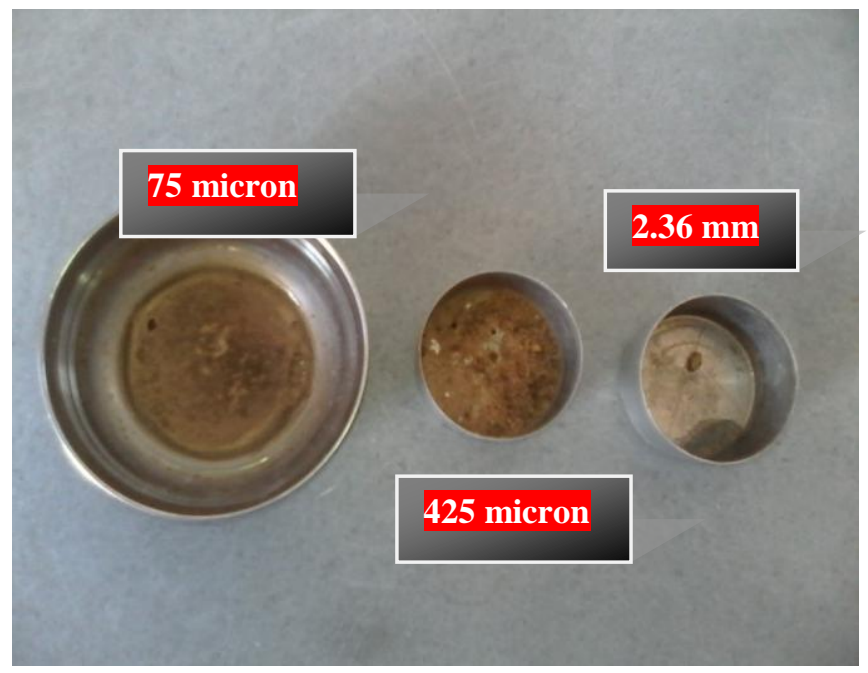

Fig 2: samples collected from sieves

\subsection{Atterberg's Limits IS 2720 (Part V) 1985}

\subsubsection{Liquid Limit:}

1. The liquid limit device shall be inspected to determine that it is clean, dry and in good working order, that the cup falls freely and it does not have too much side play at its hinge. The grooving tool shall also be inspected to determine that it is clean and dry.

2. About $120 \mathrm{gm}$ of the soil sample passing 425 -micron sieve shall be mixed thoroughly with distilled water in the evaporating dish or on the flat glass plate to form a uniform paste. The paste shall have a consistency that will requi9ire 30 to 35 drops of the cup to cause the consistency closure of the standard groove. In case of clayey soil, the soil paste shall be left for a sufficient time ( 24 hours ) so as to ensure uniform distribution of moisture throughout the soil mass.

3. Take a portion of the paste in the spatula and place it in the centre of the cup so that it is almost half filled. Level off the cup surface of the wet soil with the spatula, so that it is parallel to the rubber base and maximum depth of the soil is $1 \mathrm{~cm}$.

4. Cut a groove in the wet soil in the cup by using appropriate grooving tool.

5. Turn the handle of the apparatus at the rate of 2 revolutions per seconds until the two parts of the soil come in contact with bottom of the groove along the distance $10 \mathrm{~mm}$. record the numbers of blows required to cause the groove close to $10 \mathrm{~mm}$.

6. Collect the representative slice of soil from cup and put it in a airtight container, determine water content of the sample.

7. Remove the soil from the cup and mix it with the soil left earlier on the glass plate. Change the consistency of the mix by adding more water or leaving the soil paste dry. repeat the above steps $3,4,5, \& 6$. Note the numbers of blows to close the groove and keep the soil for water content determination.

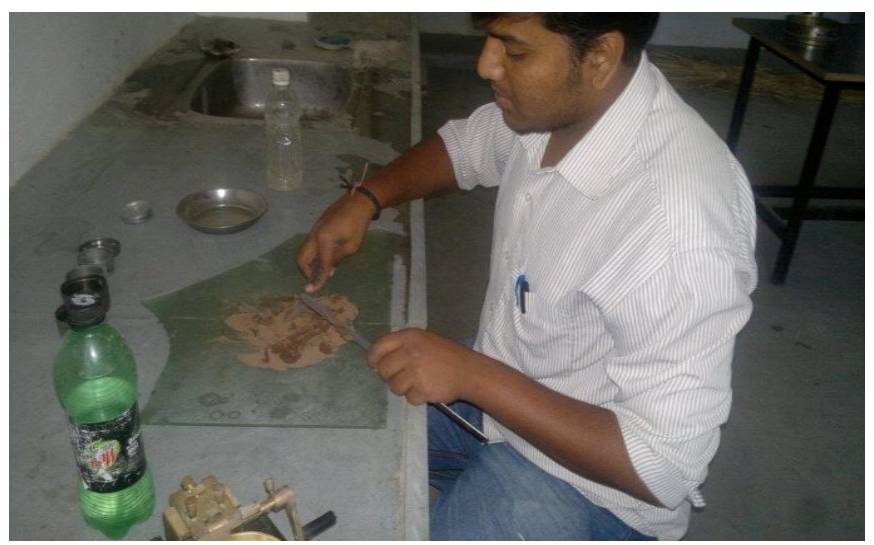

Fig 3: mixing soil thoroughly 


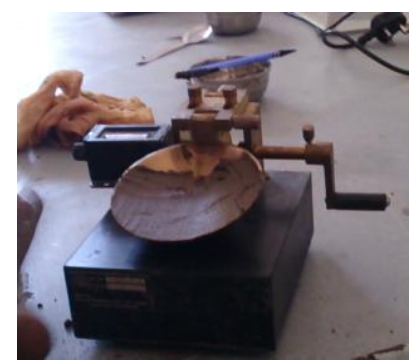

Fig 4: filling 2/3 with soil

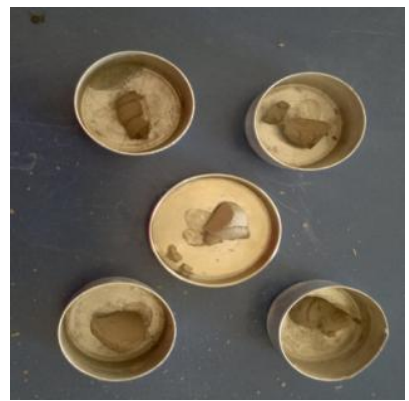

Fig 6: collecting samples
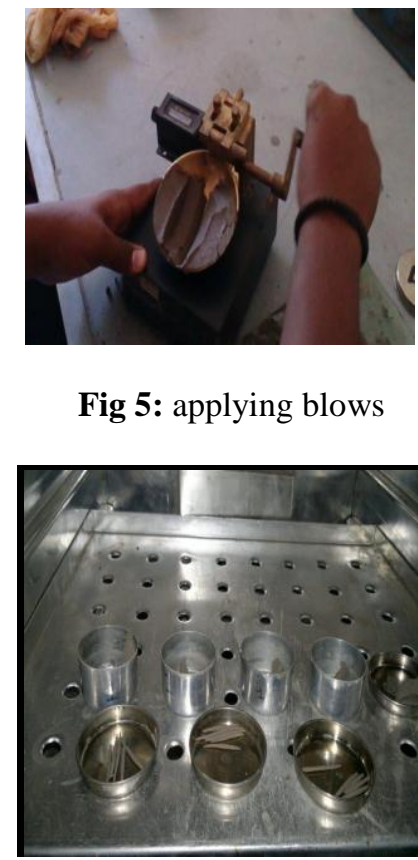

Fig 5: applying blows

Fig 7: putting samples in oven

\subsubsection{Plastic Limit}

1. Take about $120 \mathrm{gm}$ of dry soil passing through the 425 micron IS sieve.

2. Mix the soil with distilled water on a glass plate to make it plastic enough to shape into a small ball.

3. Leave the plastic soil mass for some time for maturing.

4. Take about $8 \mathrm{gm}$ of the plastic soil, and roll it with fingers on a glass plate, when a diameter of the thread has decreased $3 \mathrm{~mm}$, the specimen is kneaded together and rolled out again. Continue the process until thread just crumbles at $3 \mathrm{~mm}$ dia.

5. Collect the piece of crumbled soil thread in a moisture content container for water content determination.

6. Repeat the procedure at least the twice more with fresh sample of plastic soil.

7. The average water content of three soil sample will give plastic limit.

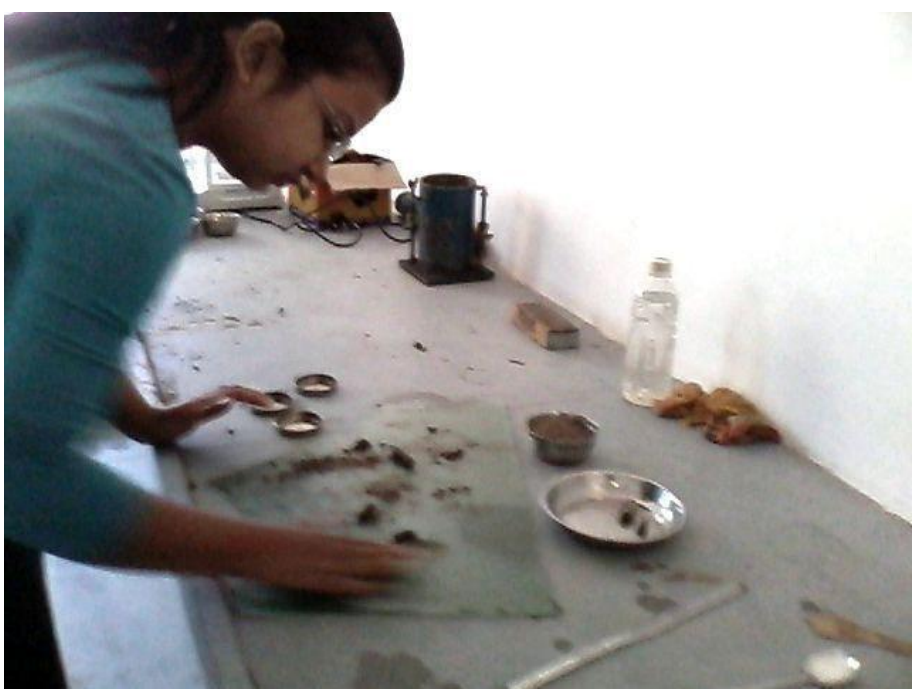

Fig 8: crumbling soil

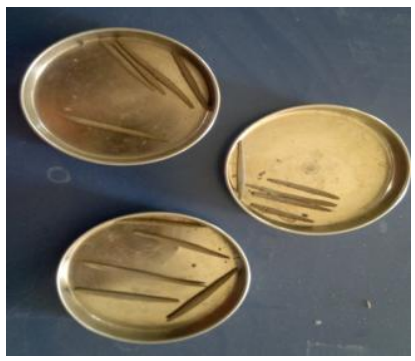

Fig 9: collecting samples

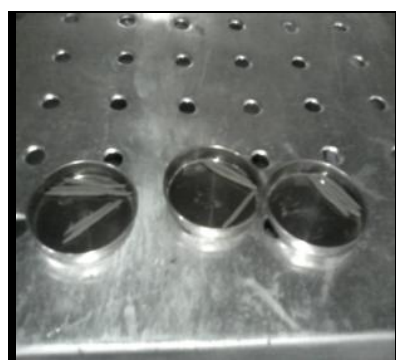

Fig 10: keeping in oven

\subsection{Modified Proctor Test IS: 2720 (Part 8) 1983}

1. $5 \mathrm{~kg}$ of sample is taken

2. Thoroughly mix it with mixing tools.

3. Fill the mixed soil sample into the standard proctor mould into 5 layers with 25 blows per layer.

4. Unmould the soil specimen.

5. Take out very small amount of sample from the centre of the specimen and weight it. Put it into the oven for 24 hours for drying.

6. After completion of time period again weight the sample and note the difference in weight.

7. Repeat whole process until value increase again.

8. Plot the values and get OMC \& MDD. 


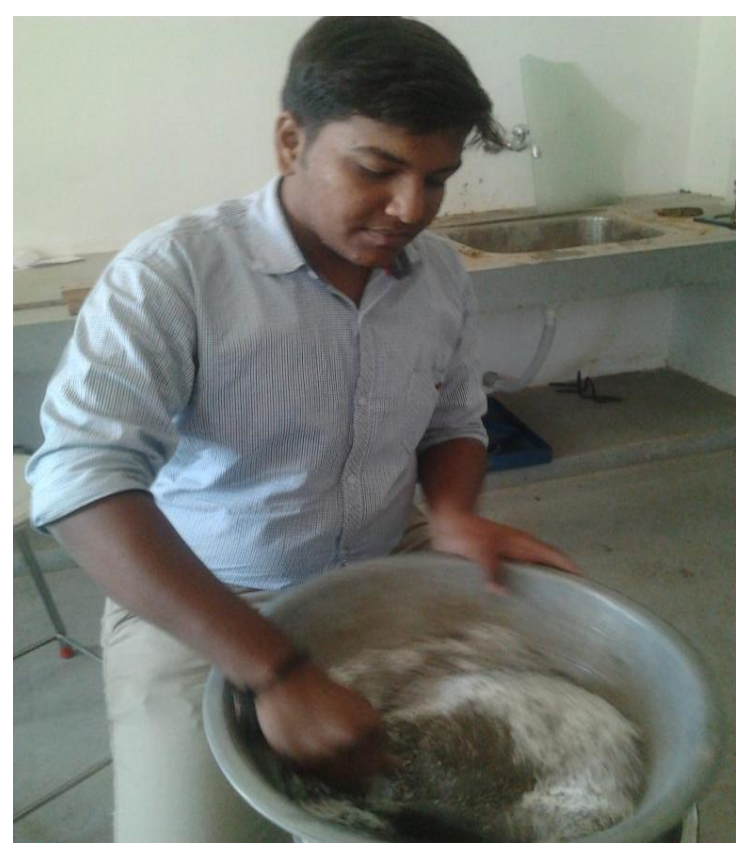

Fig 11: mixing soil

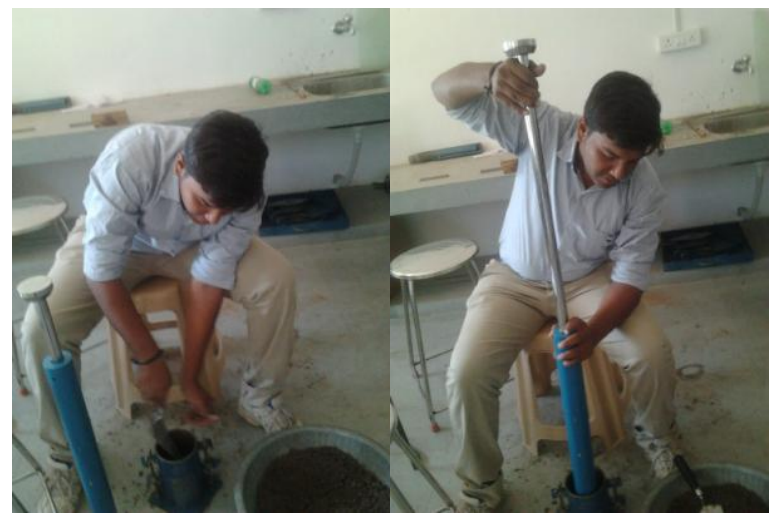

Fig 12: Moulding soil by five layer at 25 blows at each layer

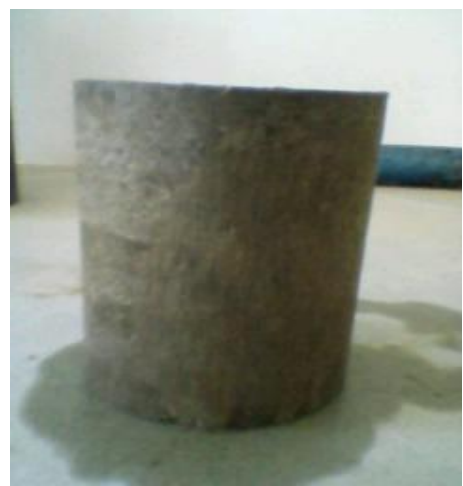

Fig 13: unmoulded soil block
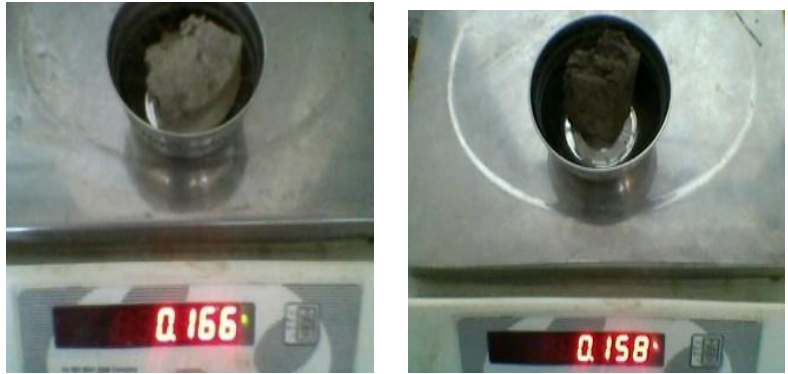

Fig 14: sample weight Fig 15: weight of oven dried sample

\subsection{Linear Shrinkage IS 2720 (Part 20)-1992}

1 The mould shall be thoroughly cleaned and a thin film of grease shall then be applied to its inner walls in order to prevent the soil from adhering to the mould.

2 About $150 \mathrm{~g}$ of the soil sample passing 425 micron IS Sieve shall be placed on the flat glass plate and thoroughly mixed with distilled water, using the palette knives, until the mass becomes a smooth homogeneous paste, with moisture content approximately 2 percent above the liquid limit of the soil. In the case of clayey soils, the soil paste shall be left to stand for a sufficient time $(24 \mathrm{~h})$ to allow the moisture to permeate throughout the soil mass.

3 The thoroughly mixed soil-water paste shall be placed in the mould such that it is slightly proud of the sides of the mould. The mould shall then be gently jarred to remove any airpockets in the paste. The soil shall then be levelled off along the top of the mould with the palette knife. The mould shall be placed so that the soil-water mixture (paste) can air. dry slowly, until the soil has shrunk away from the walls of the mould. Drying should then be completed first at a temperature of 60 to $65^{\circ} \mathrm{C}$ until shrinkage has largely ceased and then at 105 to $110^{\circ} \mathrm{C}$ to complete the drying.

4 The mould and soil shall then be cooled and the mean length of. Soil bar measured if the specimen has become curved during drying. The measurement should be made along the mean arc.

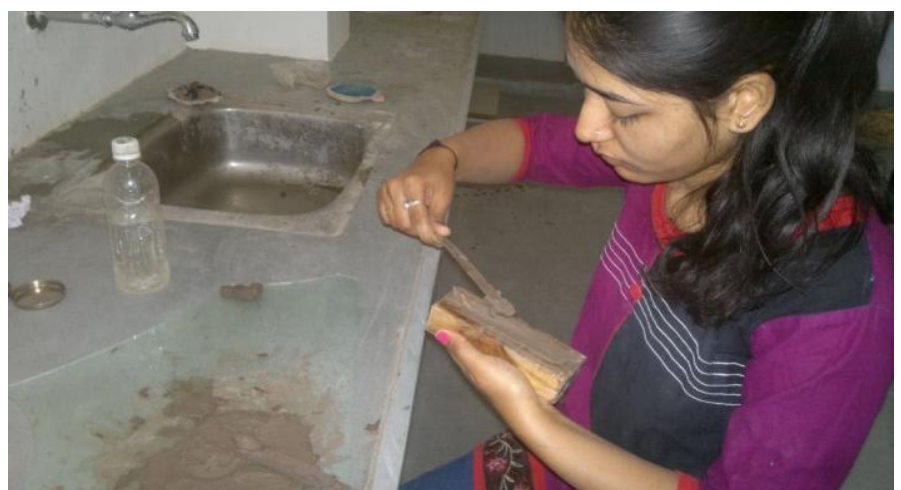

Fig 16: filling mould with soil 


\subsection{Swelling Index}

1. Take two $10 \mathrm{~g}$ soil specimens of oven dry soil passing through 425-micron IS Sieve.

2. In the case of highly swelling soils, such as sodium bentonites, the sample size may he $5 \mathrm{~g}$ or alternatively a cylinder of $250 \mathrm{ml}$ capacity may be used.

3. Each soil specimen shall be poured in each of the two glass graduated cylinders of $100 \mathrm{ml}$ capacity. One cylinder shall then be filled with kerosene oil and the other with distilled writer up to the $100 \mathrm{ml}$ mark. After removal of entrapped air, the soils in both the cylinders shall be allowed to settle. Sufficient time (not less than $24 \mathrm{~h}$ ) shall be allowed for the soil. sample to attain equilibrium state of volume without any further change in the volume of the soils. The final volume of soils in each of the cylinders shall be read out.

\section{RESULTS AND DISCUSSION}

\subsection{Atterberg's Limits}

Table 3: Atterbg's limit values for mix proportions of soil \& brick dust

\begin{tabular}{|l|c|c|c|c|}
\hline & $\begin{array}{l}\text { black } \\
\text { cotton } \\
\text { soil }\end{array}$ & $30 \%$ BD & $40 \%$ BD & $50 \%$ BD \\
\hline $\begin{array}{l}\text { Liquid Limit } \\
(\%)\end{array}$ & 43 & 33.5 & 32.5 & 29.3 \\
\hline $\begin{array}{l}\text { Plastic Limit } \\
(\%)\end{array}$ & 16.89 & 12.96 & 12.77 & 11.43 \\
\hline $\begin{array}{l}\text { Plasticity Index } \\
(\%)\end{array}$ & 26.1 & 20.53 & 19.72 & 17.86 \\
\hline
\end{tabular}

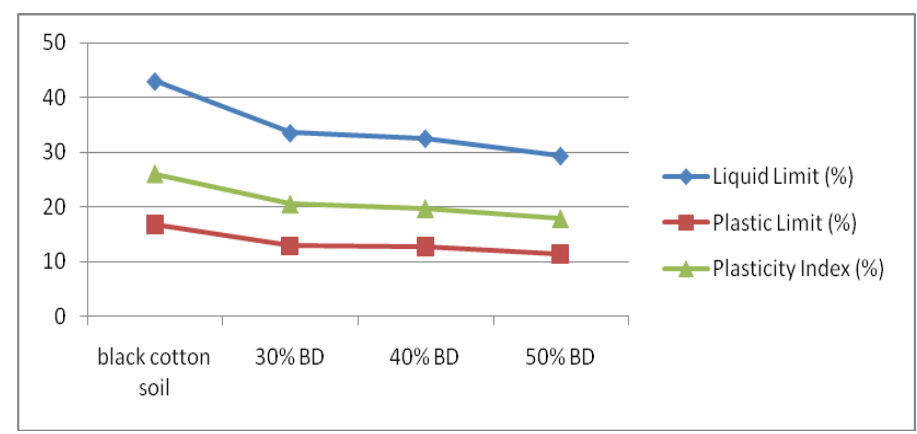

Chart 1:- atterberg's limit chart of replacement of brick dust

By the replacement of black cotton soil from the burnt brick dust it is identified that the values of attereberg's limits are decreasing with increasing the stabilizing content. Above figure shows that the liquid limit values for $30 \%$ replacement are nearly equal to 33 which $22 \%$ less than the black cotton soil value. As same for $40 \%$ replacement liquid limits value decrease by $24.41 \%$ and for $50 \%$ burnt brick dust it reduced by $31.86 \%$. As same reduction is identified plastic limit and plasticity index. Reduction in plastic limit value for 30, 40, 50 $\%$ burnt brick dust are respectively $23.29,24.42, \& 32.35 \%$. As same reduction in plasticity index for $30,40,50 \%$ brick dust are respectively $21.34,24.44, \& 31.57 \%$.

\subsection{Modified Proctor Test}

Table 4: Modified proctor test values for mix proportions of soil \& brick dust

\begin{tabular}{|l|c|c|c|c|}
\hline CONTENT & $\begin{array}{l}\text { black } \\
\text { cotton soil }\end{array}$ & $30 \% \mathrm{BD}$ & $40 \% \mathrm{BD}$ & $50 \% \mathrm{BD}$ \\
\hline MDD $(\mathrm{g} / \mathrm{cc})$ & 1.71 & 1.81 & 1.875 & 1.937 \\
\hline OMC $(\%)$ & 18.08 & 15.55 & 14.3 & 11.69 \\
\hline
\end{tabular}

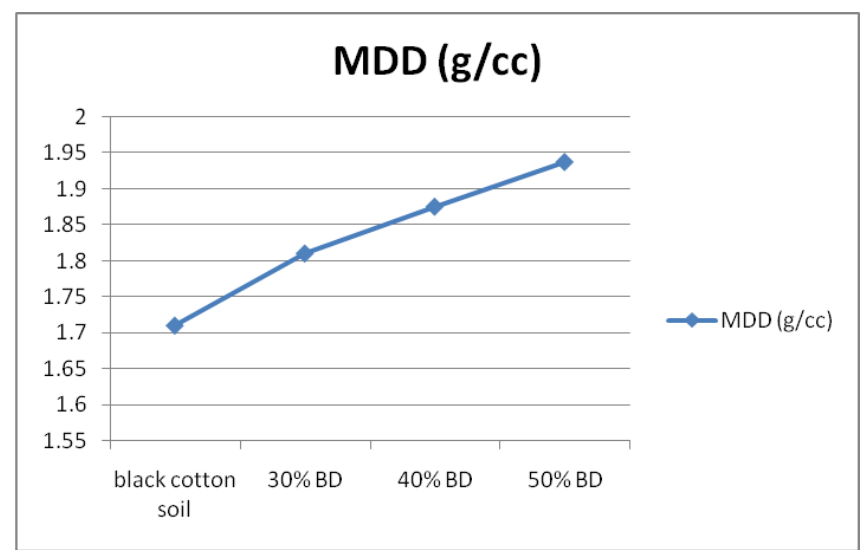

Chart 2: maximum dry density for mix proportions soil \& brick dust

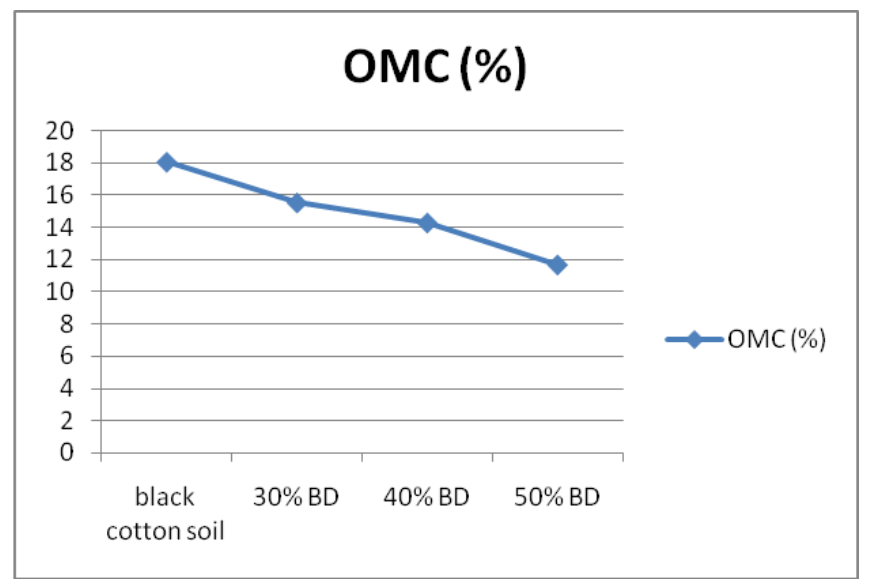

Chart 3: optimum moisture content for mix proportions soil \& brick dust

The above figure is showing the impact of brick dust on maximum dry density and optimum moisture content. Form the figure it is concluded that with the increasing amount of 
marble powder by percentage weight of black cotton soil dry density is increasing and optimum moisture content is decreasing. For replacement of soil maximum dry density is increasing by $5.84 \%, 9.64 \%$, \& $13.27 \%$ for $30 \%, 40 \%$, \& $50 \%$ marble powder respectively. And optimum moisture content for the same is decreasing by $13.99 \%, 20.90 \%, \& 35.34 \%$ than the black cotton soil.

\subsection{Linear Shrinkage}

Table 5: Linear shrinkage values for mix proportions of soil \& brick dust

\begin{tabular}{|c|c|c|c|c|}
\hline $\begin{array}{c}\text { mix } \\
\text { proportion }\end{array}$ & $\begin{array}{c}\text { black } \\
\text { cotton } \\
\text { soil }\end{array}$ & $\begin{array}{l}\mathrm{BC}+ \\
30 \% \mathrm{BD}\end{array}$ & $\begin{array}{l}\mathrm{BC}+ \\
40 \% \mathrm{BD}\end{array}$ & $\begin{array}{l}\mathrm{BC}+ \\
50 \% \mathrm{BD}\end{array}$ \\
\hline $\begin{array}{c}\text { shrinkage } \\
\%\end{array}$ & 23.7 & 9.4 & 7.8 & 7.3 \\
\hline
\end{tabular}

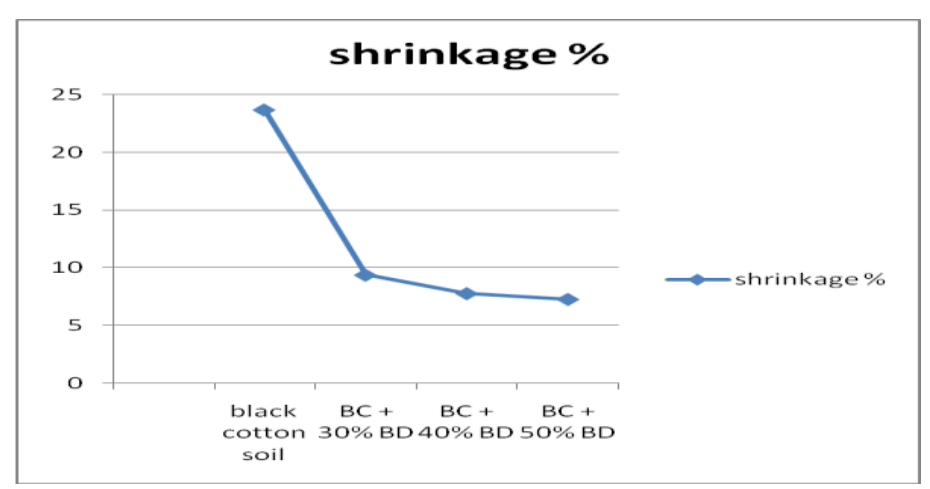

Chart 4: linear shrinkage chart for mix proportions soil \& brick dust

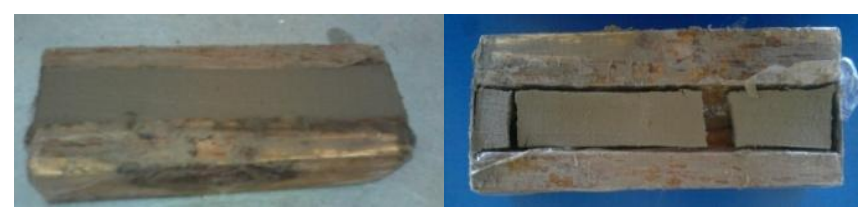

Fig 17: expansive soil with cracks due to shrinkage

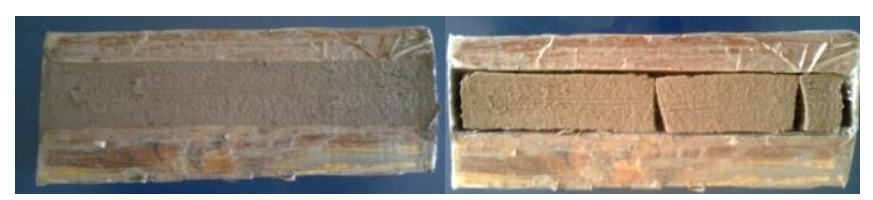

Fig 18: shrinkage showing soil $+30 \%$ brick dust

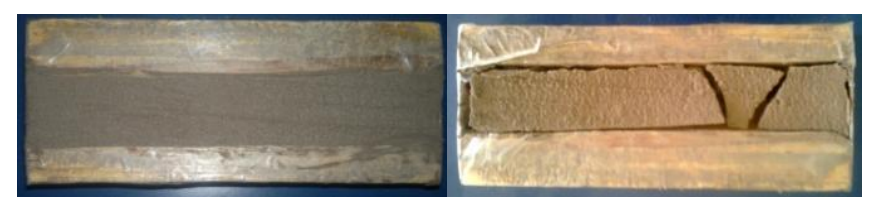

Fig 19: shrinkage showing soil $+40 \%$ brick dust

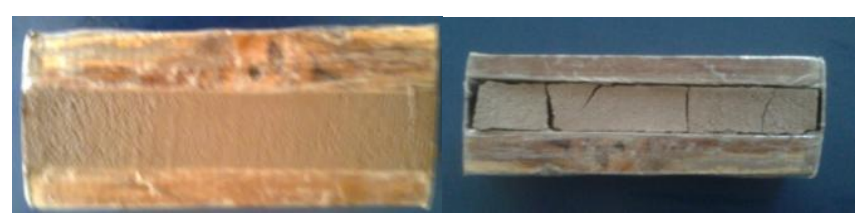

Fig 20: shrinkage showing soil $+50 \%$ brick dust

The reading shows that with increasing brick dust content the linear shrinkage is reducing. For $30 \%, 40 \% \& 50 \%$ it reduces $60.33 \%, 67.08 \%$ \& $69.19 \%$ respectively than the black cotton soil.

\subsection{Free Swell Index}

Table 6: Free swell index values for mix proportions of soil \& brick dust

\begin{tabular}{|c|c|c|l|l|l|}
\hline $\begin{array}{l}\text { free } \\
\text { swell } \\
\text { index }\end{array}$ & $\begin{array}{c}\text { mix } \\
\text { proportion }\end{array}$ & $\begin{array}{c}\text { black } \\
\text { cotton } \\
\text { soil }\end{array}$ & $\begin{array}{l}\mathrm{BC}+ \\
30 \% \\
\mathrm{BD}\end{array}$ & $\begin{array}{l}\mathrm{BC}+ \\
40 \% \\
\mathrm{BD}\end{array}$ & $\begin{array}{l}\mathrm{BC}+ \\
50 \% \\
\mathrm{BD}\end{array}$ \\
\hline 1 & $\begin{array}{c}\text { The initial } \\
\text { volume }\end{array}$ & $10 \mathrm{ml}$ & $10 \mathrm{ml}$ & $10 \mathrm{ml}$ & $\begin{array}{l}10 \\
\mathrm{ml}\end{array}$ \\
\hline 2 & $\begin{array}{c}\text { The final } \\
\text { volume }\end{array}$ & $15.05 \mathrm{ml}$ & $11 \mathrm{ml}$ & $10.5 \mathrm{ml}$ & $\begin{array}{c}10 \\
\mathrm{ml}\end{array}$ \\
\hline 3 & $\begin{array}{c}\text { Free swell } \\
\text { index }\end{array}$ & $50.50 \%$ & $10 \%$ & $5 \%$ & $0 \%$ \\
\hline
\end{tabular}

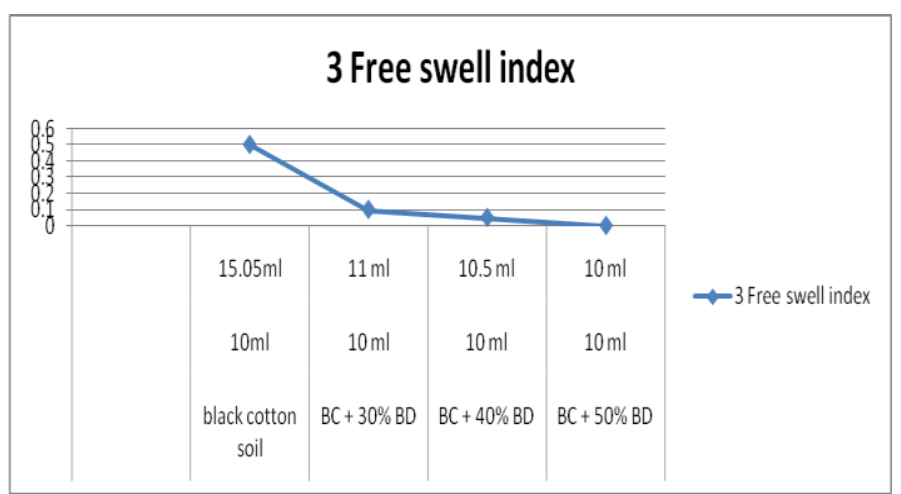

Chart 5:- free swell index chart for mix proportions soil \& brick dust
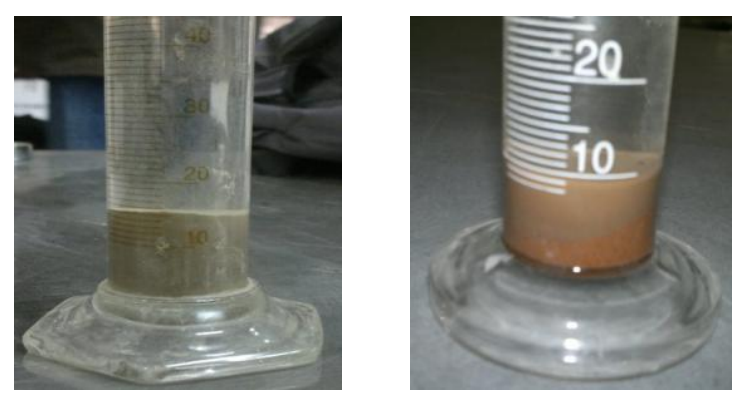

Fig 21: swelling B.C soil Fig 22: swelling B.C soil + 30\% BD 


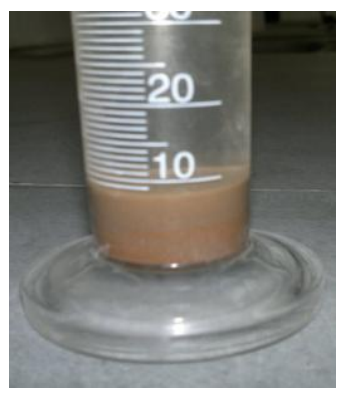

Fig 23: swelling B.C soil $+40 \% \mathrm{BD}$

With increasing the burnt brick dust content the swelling index is decreasing which shows reduction in swell index with increment in stabilizing content.

\section{CONCLUSIONS}

From the results it is concluded that the impact of brick dust on black cotton soil is positive. By replacing soil by half of its dry weight by brick dust it gives maximum improvement in the engineering properties of black cotton soil. So use of brick dust is preferable for stabilization because it gives positive results as stabilizer and also it is a waste utilization.

\section{ACKNOWLEDGEMENTS}

We are very thankful to Mr. Ankit Patel (M.TECH Structure) who have been constant source of inspiration, guidance and encouragement. We are also very thankful to our principal Dr. V. M. Patel for always being there for us.

\section{REFERENCES}

[1] "Problems related to black cotton soil" Gourley et al. 1993

[2] "Expansive soil stabilization using marble dust". Vinay Agrawal and Mohit Gupta. International journal of earth sciences and engineering. ISSN 0974-5904, Volume 04, No 06 SPL, October 2011, pp 59.

[3] "WOVEN GEO TEXTILE TFI 5300 FOR SUBGRADE STABILIZATION" Public Works Department Pune/ Integrated Public Works Division, Pune.M/s H.J.Tekawade, Taluka-Purandhar, DistrictPune. CASE HISTORY TECHFAB INDIA

[4] "Effect of lime on the index properties of black cotton soil and mine tailings mixtures" H.N.Ramesh, A.J.Krishnaiah and S.Shilpa shet. IOSR Journal of Engineering (IOSRJEN) e-ISSN: 2250-3021, p-ISSN: 2278-8719 Vol. 3, Issue 4 (April. 2013), ||V3|| PP 0107.

[5] "Behaviour of black cotton soil reinforced with sisal fibre" santhi Krishna k. and sayida m. k. $10^{\text {th }}$ national conference on technological trends (NCTT09) 6-7 November 2009.
[6] "Stabilization of expansive soils using fly ash" S. Bhuvaneshwari, R. G. Robinson, S. R. Gandhi. Fly ash India 2005, New Delhi.

[7] "Stabilization of expansive soil with rice husk ash, lime and gypsum - an experimental study". Koteswara Rao. D. and Anusha M. international journal of engineering science and technology (IJEST). ISSN: 0975-5462 Vol. 3 No. 11 November 20118076.

\section{BIOGRAPHIES}

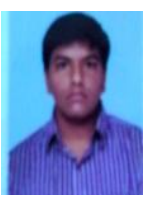

Mr. Sachin Bhavsar, B. E. civil engineering student;Shankersinh vaghela bapu institute of technology, unava , Gandhinagar

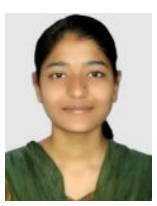

Miss. Hiral Joshi, B. E. civil engineering student;Shankersinh vaghela bapu institute of technology, unava, Gandhinagar

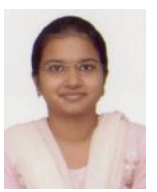

Miss. Priyanka Shrof, B. E. civil engineering student;Shankersinh vaghela bapu institute of technology, unava, Gandhinagar

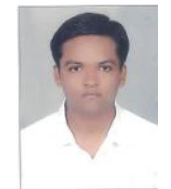

Mr.Ankit patel, Assistant professor ,Svbit. He has experience of about 2 years in teaching, he has guided more than 15 students of UG program in different field like - rain water harvesting ,concrete technology and geotechnical engineering etc.... 